\title{
KEPULAUAN ARU DAN INTEGRASI KEBANGSAAN DALAM PERSPEKTIF SEJARAH DAN BUDAYA ${ }^{1}$
}

\author{
The Aru Islands and Nation Integrity in the Cultural \\ and Historical Perspective
}

\author{
Mezak Wakim \\ Balai Pelestarian Nilai Budaya Ambon \\ mwakim@gmail.com
}

Naskah diterima: 10-01-2014; direvisi: 21-04-2014; disetujui: 09-05-2014

\begin{abstract}
National integration is a central issue in the context of the management of the foremost islands in Indonesia. Aru Islands is one of the areas in Moluccas which became the region's leading Indonesian island. This paper aims to address issues related to the Aru Islands national integration as one of the leading regions in Indonesia. Discussions focused on the perspective of history and culture as one of the approaches in addressing the issue of national integration. Therefore, use literature to illustrate the historical and cultural Aru Islands. The results of the discussion of an understanding that the similarity of historical and cultural background of the Aru Islands and surrounding areas provide awareness of the importance of national integration in the management of the outer islands in Indonesia.
\end{abstract}

Keywords: Aru, National Integration, Advanced Island, Cultural History

\begin{abstract}
Abstrak
Integrasi kebangsaan merupakan isu sentral dalam konteks pengelolaan pulau terdepan di Indonesia. Kepulauan Aru adalah salah satu wilayah di Maluku yang menjadi kawasan bagi pulau terdepan di Indonesia. Tulisan ini bertujuan untuk menjawab permasalahan terkait isu integrasi kebangsaan bagi Kepulauan Aru sebagai salah satu wilayah terdepan di Indonesia. Pembahasan difokuskan pada perspektif sejarah dan budaya sebagai salah satu pendekatan dalam menjawab isu integrasi kebangsaan. Oleh karena itu, digunakan studi pustaka untuk memberi gambaran historis dan kultural Kepulauan Aru. Hasil pembahasan memberi pemahaman bahwa kesamaan latar belakang historis dan kultural Kepulauan Aru dan sekitarnya memberi kesadaran akan pentingnya integrasi kebangsaan dalam pengelolaan pulau-pulau terdepan di Indonesia.
\end{abstract}

Kata kunci: Aru, Integrasi Kebangsaan, Pulau Terdepan, Sejarah Budaya

\section{PENDAHULUAN}

Alfred Russell Wallace seorang naturalis Inggris yang tiba di Dobo tepatnya di Pulau Wamar pada pertengahan abad ke-19 bertugas melakukan suatu eksplorasi wilayah-wilayah Timur (1854-1862). Hasil eksplorasinya menyebutkan pulau-pulau Aru sebagai The Promised Land (tanah terjanji) hal mendasar yang didapatkan dari teori ilmuwan ini adalah keagungan atas keanekaragaman hayati pulau-pulau Aru dan jenis kerangkerangan laut yang belum pernah dilihatnya di belahan dunia lain. Hasil penelitian Wallace di Aru kemudian disatukan sebagai sebuah karya ilmiah bersama kajiannya yang juga mencakup wilayah lain di Asia Tenggara yang dikunjunginya. Dalam buku berjudul The Malay Archipelago ini, Wallace

\footnotetext{
${ }^{1}$ Naskah ini pernah disampaikan pada Kemah Guru SMA di Wilayah Perbatasan Nasional (KAWASAN) di Kabupaten Kepulauan Aru, Provinsi Maluku pada tanggal 15-19 Oktober 2012
} 
mengemukakan teorinya, dengan mengacu pada distribusi hewan dan burung, yang secara total ilmuwan dunia ini mengumpulkan lebih dari sembilan ribu spesimen objekobjek alam dari sekitar seribu enam ratu spesies (Wallace, 2009; Spriggs et.al, 2005 1-4). Dari rekaman referensi yang ditemukan Wallace tentu memberikan pertimbangan atas keunggulan pulau-pulau kecil yang sering terabaikan dalam dimensi pembangunan nasional. Pulau-pulau Aru yang berbatasan dengan negara tetangga seperti Papua Nugin dan Australia tentu akan menjadi kepentingan geo-politik sebagai satu kekuatan otonom dari negara-negara tersebut. Indonesia yang kini belajar dari eksistensi kepulaua sebagai integrasi nasional sangat perlu mempertimbangkan pulau-pulau kecil sebaga bagian terdepan dari kedaulatan bangsa

Orientasi kita terhadap "pulau-pulau terdepan atau terluar" tentu akan mengac pada pulau-pulau kecil yang terabaikan namun dampak yang ditimbulkan kin menjadi pertimbangan nasional. Hilangnya beberapa pulau kecil di Indonesia seperti Sipadan dan Ligitan, pemerintah Indonesia baru dikejutkan dengan semangat untuk menyiapkan berbagai proyek besar dalam kerangka pemberdayaan masyarakat $d$ wilayah perbatasan. Kata terlambat sering menjadi tradisi bangsa ini manakala berbagai kepentingan nasional baik yang berhubungan dengan eksistensi pulau maupun karyabudaya yang diklaim bangsa lain, barulah kemudian ada kepedulian. Namun demikian, lebih baik memulainya dari pada tidak sama sekali. Kepedulian terhadap pulau-pulau terdepan di Indonesia satu di antaranya di Kepulauan Aru sangat penting dalam menjaga keutuhan ke-Indonesia-an.

Membicarakan pulau dalam eksistensi kepentingan nasional tentu orientasi pemikiran akan menunjuk pada seluruh kewilayahan Negara Kesatuan Republik Indonesia yan materialisasinya meliputi "tanah" dan "air" Kolaborasi pemaknaan ini akan memberikan satu konsep mendasar bahwa negara Indonesia terdiridari tanah (pulau-pulau)dan air (laut Bagi bangsa Indonesia, keberadaan tanah (pulau-pulau) dan air (laut) memang tidak tara yang satu dengan lainya. Pulau-pulau yang diakui sebaga satu kesatuan tentu menjadikan Indonesia kuat dengan konsep wawasan Nusantara yang mempertemukan keberagaman pulaupulau dengan karaktersitik masyarakat yang berbeda-beda. Dalam literatur Indonesia tentang geografi atau politik (juga tentang sejarah, ekonomi, sosial dan budaya) sering dijumpai pernyataan-pernyataan yang berbunyi "Laut Jawa menghubungkan Pulau Jawa dengan Pulau Kalimantan, Selat Sunda menyatukan Pulau Sumatera dengan Pulau Jawa, Selat Makassar menghubungkan Pulau Sulawesi dan Pulau Kalimantan" dan lain sebagainya. Pulau-pulau dan laut itu saling ari proses itulah ahirnya Indonesia.

Dalam perspektif sejarah, lahirnya konsepsi Djuanda tahun 1957 yang diperkua dengan Wawasan Nusantara yang dituangkan dalam ketetapan MPR No II/MPR/1988 merupakan tonggak penting pengakuan bangsa Indonesia terhadap keterpaduan tanah (pulau-pulau) dan air (laut) bagi penyatuan dan kesatuan bangsa. Keputusan ini tentu telah merekomendasikan Indonesia sebagai negara kepulauan, sebuah negara yang menegaskan prinsip dasar yang mengutamakan konsep kewilayahan negara kesatuan Indonesia yang terdiri dari pulau-pulau dan laut sebagai satu sistemik dari unsur kebangsaan yang meliputi politik, ekonomi, sosial, budaya, pertahanan dan keamanan yang utuh serta tidak bisa dilepas pisahkan.Pengelolaan pulau-pulau yang dimaksudkan dalam pendekatan in sering dipertemukan dengan isu pengelolaan wilayah perbatasan, sebagai beranda terdepan Indonesia (Susilo, 2007).

$$
\text { Di Indonesia, isu perbatasan semakin }
$$
menghangat dan menjadi topik utama dalam berbagai perbincangan pada tingkat Eksekutif Legislatif, tak ketinggalan pula berbaga komponen Lembaga Swadaya Masyarakat (LSM) melontarkan komentar dan pemikiran kritis tentang problem perbatasan. Komentar tersebut kadangkala membangkitkan 'emosi” kebangsaan sesaat'. Bisa dimaklumi, karena perbatasan berhubungan erat dengan wilayah kedaulatan negara. Kas sempat terangkat luas ke publik antara lain reklamasi pantai Singapura, penutupan 4 pintu perbatasan darat di Belu, dan Blok Ambalat yang mulai mencuat. Kasus proyek reklamasi pantai Singapura yang berlangsung sejak tahun 1960 dikhawatirkan berdampak negatif terhadap lingkungan dan sumberdaya perikanan. Kekhawatiran dari sejumlah pihak akan ter pihak akan kedaulan negara akibat reklamasi juga patut dicermati. Persoalan semakin kompleks ketika pasir untuk keperluan reklamasi Singapura diambil dari wilayah perairan Kepulauan Riau. Beberapa pulau di kawasan ini dikhawatirkan tenggelam. Di sisi lain, luas daratan Singapura meningkat dalam kurun waktu tertentu. Tercatat par Tercatat pada tahun 1960 luas asli Singapura sebesar $580 \mathrm{~km}$. Bertambah menjadi 660 $\mathrm{km}$ sampai tahun 1999, bahkan peningkatan drastis terjadi pada tahun 2002 menjadi 680 $\mathrm{km}^{2}$. Demikian halnya laporan Departemen Kelautan dan Perikanan pada tahun 2002, bahwa Singapura mampu mereklamasi atau memperluas daratan seluas $120 \mathrm{~km} 2$ (Satia km2 (Satria, 2009: 49)

Kepentingan pulau-pulau yang ada di Indonesia dengan sejumlah permasalahan mendasar tentu menjadi bagian dari keterpaduan kebijakan politik bangsa yang tidak dapat dikesampingkan. Tentu sebagai wilayah kepulauan berbagai kebijakan politik yang menyentuh pulatpulau politik yang menyen berimban tidak berimbang akibatnya, pergerakan pembangunan infrastruktur seperti jalanan, listrik, air bersih, sarana transportasi dan komunikasi hanya terkonsentrasi pada kawasan kategori pulau besar. Faktor inilah yang menjadi pemicu utama pembangunan pulau-pulau kecil tertinggal jauh. Lepasnya pulau Sipadan dan Ligitan ke pihak Malaysia menjadi pelajaran berharga bagi Indonesia. menjadi pelajaran berharga bagi Indonesia. Walaupun menurut perjanjian Inggris dan Belanda, kedua pulau tersebut masuk wilayah Indonesia, tetapi Mahkamah Internasional lebih menitikberatkan pada bukti peranan utama yang dijadikan alasan Mahkamah
Internasional memenangkan Malaysia yakni keberadaan secara terus menerus (continuous presence), penguasaan efektif (effective occupation), dan pelestarian ekologis (ecology preservation). Indonesia lemah dalam ketiga hal tersebut dibanding Malaysia. Kekhawatiran terhadap keberadaan pulau kecil terdepan tidak terbatas pada lepasnya pulau ke negara lain. Letaknya yang berhadapan langsung dengan 10 negara tetangga (Singapura, Malaysia, Thailand, India, Vietnam, Palau, Papu Nugini, Australia, Philipina, dan Timor Leste) berpotensi rawan terhadap pengaruh ideologi, ekonomi, politik, sosial-budaya, dan pertahanan keamanan.

Dalam kerangka permasalaha mendasar terkait dengan wilayah-wilayah perbatasan tersebut, tulisan ini membahas tentang Kepulauan Aru yang merupakan salah satu wilayah yang berbatasan langsung dengan Australia. Konteks pembahasan akan difokuskan pada aspek kesejarahan dan budaya yang melatari Kepulauan Aru sebagai bagian integrasi Negara Kesatuan Republik Indonesia.

\section{METODE}

Metode yang digunakan dalam tulisan ni adalah penelusuran sumber-sumber pustaka, baik buku-buku teks maupun hasil-hasil penelitian terdahulu terkait dengan sejarah Kepulauan Aru dan aspekspek budaya masyarakat Kepulauan Aru. Studi pustaka juga dimaksudkan untuk memberi gambaran historis dan kultural Kepulauan Aru. Analisis deskriptif digunakan untuk menjawab permasalahan tentang latar belakang historis dan kultural Kepulauan Aru dan sekitarnya.

\section{HASIL DAN PEMBAHASAN}

Kepulauan Aru : Beranda Terdepan Indonesia di Wilayah Provinsi Maluku

Kepulauan Aru merupakan wilayah laut-pulau atau wilayah kepulauan dengan jumlah pulau sebanyak 587 buah yang terdiri dari 5 (lima) buah pulau besar yaitu pulau Kola, pulau Wokam, pulau Kobror, 
pulau Maekor dan pulau Trangan, dengan luas daratan $(6.426 .77 \mathrm{~km})$ lebih kecil bila dibandingkan dari luas laut (7,6 kali luas daratan) dan memiliki topografi wilayah yang umumnya datar dengan pantai yang berawa-rawa. Jumlah pulau yang sudah dihuni sebanyak 98 buah dan sisanya belum berpenghuni.

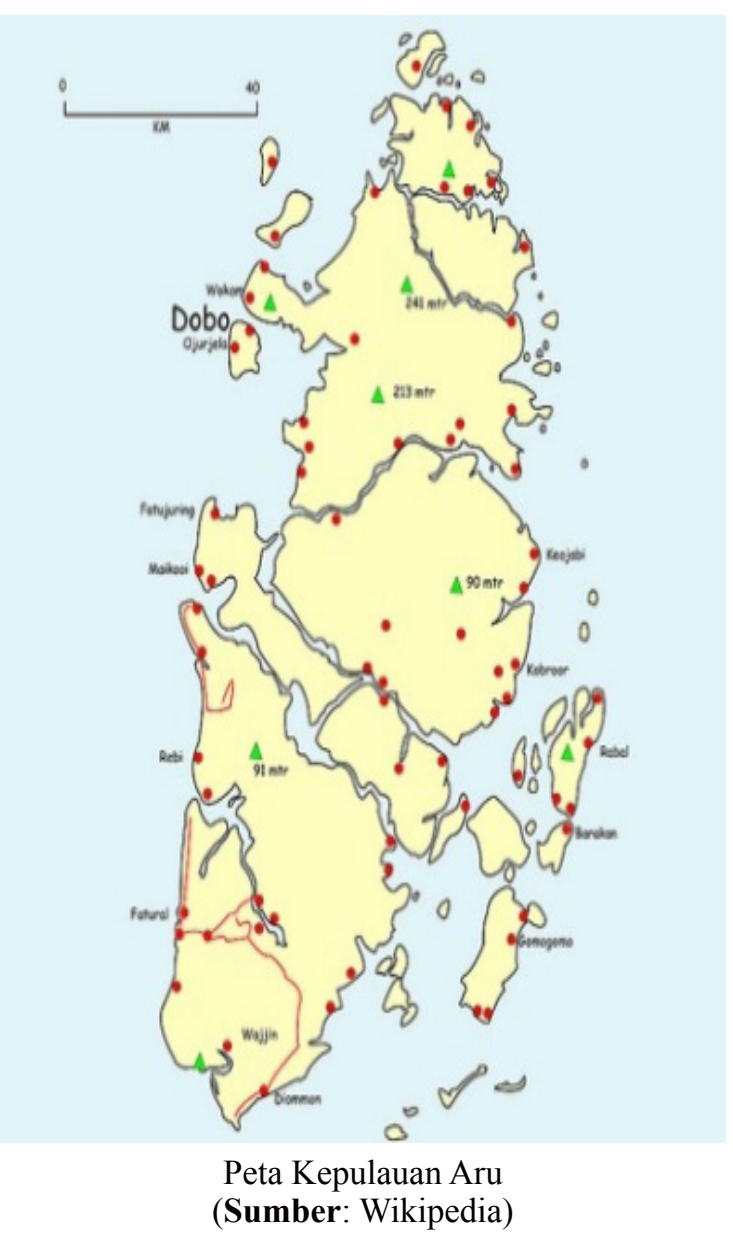

Eksistensi pulau dalam pendekatan dan orientasi kebijakan pembangunan nasiona tentu sangat perlu mempertimbangkan wilayah-wilayah yang memiliki garis perbatasan dengan negara-negara tetangga. Kepulauan Aru menjadi satu dari 19 pulau terdepan di Maluku yang memiliki peranan penting dalam kedaulatan bangsa jika di tinjau dari perspektif eksistensi pulaupulau kecil terdepan yang berbatasan dengan negara tetangga. Dalam pendekatan ini, penggunaan terminologi terluar dan terdepan yang sering dipersepsikan dalam berbagai kajian tentang pulau-pulau kecil yang berbatasan dengan negara tetangga sesunguhnya hanya mengacu pada eksistensi pulau. Dimana pulau terluar lebih disesuaikan dengan UNCLOS(United Nation Convention on the law of the sea) No 82/ 1982 yang menunjukan mengenai mekanisme penarikan garis pangkal kepulauan bagi negara-negara kepulauan (archipelagicstate), yaitu sebaga berikut: suatu negara kepulauan dapat menarik garis pangkal lurus kepulauan yang menghubungkan titik-titik terluar pulaupulau dan karang-karang terluar kepulauan itu. Sementara perkembangan penggunaan terdepan menjadi acuan terhadap eksistens pulau-pulau terluar yang dimaksudkan dalam UNCLOS 1982 menjadi bahan pertimbangan bahwa terluar sering dipersepsikan sebagai “ terabaikan, terlupakan dan lain sebagainya. Hal ini kemudian menjadi pelajaran akan hilangnya pulau-pulau kecil terdepan di Indonesia. Pemaknaan terdepan dalam pendekatan ini tentu mengacu pada keberadaan pulau-pulau kecil tersebu sebagai posisi terdepan Indonesia yang sangat perlu diperhatikan sebagai bagian dari pengelolaan isu-isu perbatasan yang kini mengancam eksistensi Negara Kesatuan Republik Indonesia.

Posisi geografis Kepulauan Aru tentu menjadi komposisi kepulauan terdepan d Maluku yang perlu diperhatikan. Pulau-pulau kecil yang bertaburan di Kepulauan Aru dengan sejumlah kepentingan perdagangan antar negara yang melirik sumber daya alam yang tersimpan rapi di pulau-pulau yang termasuk dalam gugusan Kepulauan Aru. Penempatan pulau terdepan yang dihitung dalam 92 pulau terdepan di Indonesia adalah beberapa pulau di Kepulauan Aru antara lain Pulau Panamulai, Pulau Enu, Batugoyang, Kultubai, Ararkula, Karweila. Pulau-pulau in merupakan pulau terdepan yang masuk dalam pertimbangan kebijakan pengelolaan wilayah perbatasan. Kepulauan Aru kini menjad perhatian pemerintah dalam menjadikan wilayah Kepulauan Aru sebagai gugus patroli TNI-AL di wilayah Indonesia Timur yang kini berpangkalan di Kalar-kalar. Namun demikian, perhatian tidak sebatas tersebut karena yang terpenting adalah bagaimana memetakan wilayah-wilayah perbatasan yang dikelola sebagai isu sentral pengelolaan masyarakat di wilayah perbatasan sehingga dampak adanya kepedulian akan wilayah pulau-pulau terdepan di Indonesia akan semakin diperhatikan. Kebijakan yang dilakukan tidak hanya dengan menempatkan sistem pertahanan dan keamanan pada titiktitik perbatasan antar negara, akan tetapi lebih daripada itu menempatkan kebijakan penting dalam pengelolaan kehidupan masayrakat yang berkesinambungan.

Perbatasan Indonesia hingga saat ini masih memprihatinkan dari berbagai segi. Daerah-daerah perbatasan banyak yang mengalami keterbelakangan ekonomi karena ketiadaan program dan proyek baik dari pemerintah maupun swasta. Panjangnya garis perbatasan baik di daratan maupun lautan sangat sulit untuk diawasi dengan reguler oleh aparat keamanan. Akibatnya pelanggaran wilayah perbatasan, penyelundupan, dan aktivitas ilegal lintas batas lainnya seringkali terjadi. Di beberapa daerah yang jauh dari kantor-kantor pemerintahan Indonesia, masyarakat di perbatasan justru mendapat banyak fasilitas administrasi dan pelayanan publik dari negara tetangga membuat nasionalisme mereka terbelah. Akses komunikasi dan informasi juga seringkali lebih mudah didapat dari negara-negara tetangga yang telah memajukan kawasan perbatasannya. Jika kawasan perbatasan tidak segera dikelola dengan baik dan efektif, tentu kedaulatan negara akan segera menjadi pertaruhannya.

Selama ini pemerintah dan masyarakat luas baru tersentak oleh seriusnya masalah perbatasan ketika ada ramai-ramai tentang hilangnya beberapa wilayah Indonesia karena kalah di pengadilan internasional, tau karena adanya klaim sepihak terhadap wilayah Indonesia dari negara tetangga Selain itu, karena buruknya kesejahteraan dan infrastruktur di daerah perbatasan, banyak penduduk di kawasan ini lebih memilik kedekatan emosional dan interaksi sosial ekonomi dengan masyarakat negara tetangga. Tidak jarang mereka ini mengalami krisis identitas kebangsaan berhubung rendahnya perhatian negara terhadap nasib mereka dan perkembangan daerahnya. Dalam beberapa tahun belakangan ini Pemerintah Pusat telah mengambil sejumlah kebijakan untuk menjawab persoalan yang rumit di kawasan perbatasan

Selain membentuk Badan Nasional Pengelola Perbatasan (BNPP) pada tanggal 28 Januari 2010, pemerintah juga mulai mengucurkan banyak sumber daya dan proyek pembangunan di daerah perbatasan. Pengabaian terhadap kawasan in menyebabkan berbagai kebijakan pemerintah saat ini terasa masih jauh dari memadai. Untuk itu, kemitraan bagi Pembaruan Tat Kelola Pemerintahan memandang perlunya suatu desain besar yang komprehensif untuk mengefektifkan pengelolaan kawasan perbatasan. Kemitraan mendukung terciptanya sinergi antar lembaga, revitalisas kelembagaan, maupun peningkatan sumber daya manusia dan perangkat kerja melalu berbagai kegiatan diskusi, seminar, lokakarya, penelitian, dan advokasi ke semua pemangku kepentingan guna tercapainya tujuan kawasan perbatasan yang sejahtera, maju, aman, dan menjamin kedaulatan negara.

Di Maluku, Kabupaten Kepulauan Aru tentu memiliki beberapa keunggulan tersendiri dengan daerah lain di Provinsi Maluku. Selain karena sumber daya alam akan tetapi juga banyak investasi perusahaa asing yang telah lama membentuk pola perekonomian di Kepulauan Aru. Di Benjina, Fatujuring dan wilayah lainya telah lama perusahaan-perusahan asin seperti Jepang dan beberapa negara tela 
melakukan eksplorasi terhadap kekayaan laut di Kabupaten Kepulauan Aru. Hal ini tentu telah menempatkan beberapa posisi strateg sebagai wilayah perbatasan yang banyak menimbulkan permasalahan mendasar sepert ilegal fishing, ilegal loging, dan kejahatan lainnya di wilayah perbatasan. Hal ini juga menjadi penting dalam menjadikan wilayah Indonesia khususnya di Kepulauan Aru menjadi bagian dari proyek pemerintah dalam pengelolaan wilayah perbatasan Permberdayaan masyarakat di Kepulauan Aru dengan berbagai program pemerintah, pelayanan publik, pendidikan, kesehatan, dan infrastruktur lainnya yang menyentuh kehidupan masyarakat di Kepulauan Aru, tentu merupakan program kongkrit pemerintah dalam pengelolaan wilayah perbatasan yang lebih efektif dan efisien. Dar pengalaman status kepemilikan pulau-pulau kecil yang ada, pemerintah Indonesia sering mengabaikan pengelolaanya sehingga ketika diklaim bangsa lain akan selalau kalah dalam memposisikan diri sebagai wilayah geografis milik Indonesia. Tentu sekali lagi pengalaman Sipadan dan Ligitan menjadi sejarah baru dalam pengelolaan kepemilikan pulau-pulau kecil di Indonesia sebagai bagian terdepan kedaulatan bangsa Indonesia

Kepulauan Aru Dalam Catatan Sejarah Antara Monopoli Perdagangan, Stud Hayati Hingga Kemelut Kemerdekan RI Kepentingan monopoli perdagangan cengkih dan pala di Maluku, yang dicata dalam ekspedisi The Spice Islands telah banyak memberikan perhatian bangsa Eropa dalam menelusuri dan menjelajahi kepulauan rempah-rempah di Maluku. Rekaman jejak ekspedisi yang diutarakan Antonio de Abreu dan Francisco Serrau dalam buku hariannya sebagaimana dikutip Des Alwi dalam bukunya "Sejarah Banda Naira" adalah menunjukan posisi Kepulauan Banda Naira dalam sejarah Maluku tentu memberikan penekanan penting dalam diaspora sejarah penetrasi Eropa di
Maluku. Kepulauan Aru yang masuk dalam kepentingan pemetaan monopoli perdagangan juga telah dikunjungi oleh Portugis pada abad ke-16. Catatan ini tentu disesuaikan dengan laporan ekspedisi Francisco Serrau yang menemukan Kepulauan Banda sebagai pintu masuk hegemoni Eropa atas Maluku. Pada tahun 1606, Kepulauan Aru dikunjungi pertama kali oleh Wilyam Janz dan kemudian pada tahun 1623 oleh Jan Carstenz yang memasukkan Kepulauan Aru dalam wilayah kekuasaan VOC sebagai kekuatan monopoli perdagangan rempah-rempah di Maluku (Alwi, 2006: 26-28; Sool, 2009; Wakim, 2011).

Kepulauan Aru menjadi strategis dalam monopoli perdagangan karena selain masuk dalam satu gugusan Kepulauan Maluku Tenggara, Belanda tentu sangat diuntungkan dengan berbagai keunggulan sumber daya alam di Kepulauan Aru. Dalam monopoli perdagangan yang diprakarsai VOC, posisi Kepulauan Aru banyak menyediakan sumber daya hayati, seperti kerang, mutiara, teripang, burung kakatua dan juga perdagangan burung Cendrawasih (Ricklefs, 2010:304). Pada tahun 1500 Portugis memberitahukan perdagangan burung cendrawasih dengan pasar ekspor Persia dan Turki hal ini kemudian menjadi era perdagangan yang menguntungkan VOC di masa itu.

Dari catatan sejarah, diketahui pula bahwa bulu burung cendrawasih asa Kepulauan Aru merupakan kualitas terbaik di dunia dan dipergunakan di Nepal sebaga tanda mahkota raja. Hal ini kemudian membuat kerja keras VOC untuk memikirkan Kepulauan Aru sebagai wilayah ekonom yang menguntungkan. Pada tahun 1882 di Dobo ditempatkan seorang Posthouder (wakil pemerintah Belanda) sebagai bagian dar peningkatan status wilayah dalam mengawasi pencarian mutiara di wilayah Kepulauan Aru dengan menggunakan Armada Celebes Trading Company yang mempergunakan pekerja dari luar negeri.
Selain itu juga dalam sejarah hegomoni Eropa atas Maluku tentu dekade 1942 menjadi potret buruk bagi kekuatan monopoli perdagangan Belanda di Indonesia. Ketika Jepang menguasai Asia, termasuk Maluku tercatat juga bahwa pada 12 Februari 1942 Angkatan Udara Jepang menjatuhkan bom di atas Dobo. Bom tersebut menghancurkan rumah kediaman Controleur Wolf. Kepulauan Aru mendapat perlawanan yang cukup berat dari Jepang, dan pada tanggal 30 Juli 1942, Jepang dengan kekuatan penuh mendarat di Dobo dengan demikian kekuatan Belanda pun dinyatakan selesai, dan Kepulauan Aru memasuki babak baru dalam sejarah revolusi kemerdekaan di bawah kekuatan Bala Tentara Dai Nippon. Seluruh perusahan Mutiara dikuasai Jepang untuk kepentingan perang Asia Raya.

Selain Kepulauan Aru dijadikan sebagai wilayah kekuatan monopoli pedagangan VOC, dan Jepang, namun tercatat pula pada pertengahan abad-19 di Kepulauan Aru telah dikunjungi seorang naturalis Inggris Alfred Russel Wallace yang melakukan studi hayati di Indonesia Timur antara tahun 1852-1862. Pada tahun 1857 Wallace tiba di Kepulauan Aru tepatnya di Dobo di Pulau Wamar. Dalam eksplorasi dan studi Wallace, menemukan sejumlah spesies besar kupukupu yang belum pernah ditemukan di belahan dunia manapun. Temuan Wallace terhadap seekor kupu-kupu dengan besar sayapnya sama dengan seekor burung yang dikategorikan dalam spesises Arnithoptera posidon yang sangat unik. Dalam ekplorasinya Wallace menemukan 30 spesies kupu-kupu dalam sehari sehingga membuatnya kagum atas wilayah kepulauan Aru dan kemudian menyebutnya The Promised Land (tanah terjanji) (Wallace, 2009). Catatan sejarah yang diuraikan di atas telah mengantarkan Kepulauan Aru sebagai daerah perselisihan hegemoni Barat karena keunggulan sumber daya alam dan hayati.

Perselisihan di wilayah Kepulauan
Aru tidak hanya sebatas itu, tercatat juga dalam lembar sejarah bangsa Indonesia yang telah menempatkan posisi strategis Kepulauan Aru pada konsentrasi perjuangan pembebasan Irian Barat dalam operasi Trikora pada tahun 1962. Kemelut yang menjadi prahara bangsa dalam perebutan Irian Barat adalah peristiwa 15 Januari 1962 di mana di laut Arafura terjadi pertempuran sengit antara Angkatan Laut Indonesia dan Angkatan Laut Belanda dan tercatat Laksamana Yasafa Yosudarso tewas di laut Arafura Kepulauan Aru sebagai kusuma bangsa.

Dari semua kajian aspek sejarah in tentu Kepulauan Aru selain sebagai bagia terdepan dari wilayah Indonesia di bagian timur, tentu pengalaman dari sejumlah rangkaian sejarah yang pernah tercatat dalam sejarah Kepulauan Aru sangat perlu di rangkai sebagai sebuah catatan penting bag generasi muda di Maluku dan Indonesia pada umumnya. Sebutan Kepulauan Aru dalam berbagai kepentingan nasional tentu tidak berimbang dengan berbagai kepentingan nasional yang akan diperjuangkan dari simpulsimpul ke-Indonesiaan. Pulau-pulau kecil dan terdepan tentu memberikan kotribusi penting dalam perjalanan sejarah perjuangan bangsa, hal ini sangat perlu dipikirkan manjemen pengelolaannya sebagai satu kesatuan dar unsur kebangsaan yang diperhitungkan.

Kepulauan Aru Diatas Kekuatan Local Wisdom: Pulau Terdepan Yang Menyimpan Beragam Kekayaan Budaya.

Sesunguhnya bila membaca tulisan Nico de Jong dan Tos Van Dick tentang Kepulauan Yang Terlupakan di Indonesia (Forgathen Islands) yang memuat seluruh karya budaya di Maluku Tenggara tentunya melahirkan beragam pemikiran mendasar tentang kekuatan budaya lokal dari pulaupulau yang terlupakan di Maluku termasuk di Kepulauan Aru. Eksistensi pulau terdepan yang baru dipelajari sebagai kekuatan bangsa setelah adanya ketelodoran atas kehilangan 
pulau Sipadan dan Ligitan dari sejumlah pulau kecil di Indonesia, bangsa Indonesia baru terkejut akan semangat nasionalisme yang diperjuangkan lewat berbagai proyek besar yang di kelola untuk kepentingan pulaupulau terdepan di Indonesia. Kekayaan budaya yang dimuat dalam karya monumental Nico de Jong dan Tos Van Dick mempertemukan seluruh referensi Maluku Tenggara tentang kekuatan kelokalan yang dimaterialisasikan dalam kebendaan yang ada. Dari catatan karya ini tentu Kepulauan Aru masuk dalam gugusan kepulauan yang terlupakan dari sis geografis akan tetapi kaya akan karya budaya yang bernilai tinggi (de Jong dan van Dijk 2011)

Pulau-pulau kecil tersebut merupakan pulau yang memiliki kekayaan sumber daya alam dan lingkungan yang sangat potensia juga memiliki keunikan ekosistem dan karakteristik geografis, biologis, dan cir kemasyarakat yang khas. Organisme suatu genus di satu pulau kecil dapat memilik perbedaan dengan organisasi adat di pulau lainnya organisme dari genus yang sama d pulau lainnya. Kawasan pulau-pulau keci memiliki potensi pembangunan yang cukup besar karena didukung oleh adanya ekosistem dengan produktiifitas hayati yang tinggi seperti; terumbu karang, padang lamun, rumpu laut, hutan bakau, kuda laut, kerang mutiara dan teripang. Selain itu juga jasa dibidang kebudayaan tentu menarik untuk kepentingan kepariwisataan.

Pemanfaatan kekuatan local wisdom sebagai panduan utama masyarakat dalam menelusuri unsur kebangsaan yang merekat dari kekuatan budaya, tentu pulaupulau yang ada di Kepulauan Aru memiliki kekayaan budaya lokal sebagai filosofi pemersatu masyarakat dari beragam kepulauan tersebut. Dari perspektif budaya lokal masyarakat Kepulauan Aru memang terbingka dari dua kekuatan besar secara geonologis yakni budaya $\boldsymbol{U} \boldsymbol{r s i u} \boldsymbol{w}$ dan $\boldsymbol{U} \boldsymbol{r l i m}$. Simbolisas dari kedua makna ini tentu mewakili pulau- pulau yang ada di Kepulauan Aru. Sebagai ragam dari unsur masyarakat yang memandang eksistensi pulau yang tidak terlepas dari laut sebagai kekuatan budaya bahari, maka berkembang dalam masayrakat tradisi letay Kata letay lebih dipersepsikan pada kearifan tradisional dalam pembuatan belang; (dialeg ambon; sementara Aru; letay), atau makna disesuaikan sama dengan pembuatan perahu. Tradisi ini menggambarkan sebuah kekuatan bersama dalam menyamakan seluruh ide, gagasan dalam sistem sosial budaya masyarakat dalam melihat kebudayaan letay sebagai identitas masyarakat Aru. Nilai-nilai yang melekat dari tradisi ini adalah, kebersamaan, pemeliharaan relasi sosial yang harmonis, berbagi hidup, tolong-menolong, kerja sama dan lain-lain. Selain itu juga sebagai wilayah yang jauh dari pusat modernisasi telah hidup juga kebudayaan Sitakaka Walike yang diartikan (Katong samua adalah satu; mengandung unsur satu yang menunjuk pada penyatuan keberangaman masyarakat). Sikap hidup seperti ini penting untuk terus dipelihara dan dikembangkan dalam kehidupan bermasyarakat termasuk dalam kehidupan agama-agama yang ada di wilayah Kabupaten Kepulauan Aru,yang memberi ciri tersendiri bagi masyarakat di Kepulauan Aru (Wempi, 2011). Gambaran kekuatan budaya loka ini tentu merupakan satu dari sejumlah budaya yang hidup di Kepulauan Aru yang memerlukan partisipasi pemerintah dalam memfasilitasi terwujudnya pembangunan dan pemberdayaan masyarakat Aru di Kepulauan Aru yang memiliki kesamaan yang relatif sama dengan seluruh wilayah yang ada di Indonesia. Kehidupan harmonisasi masyarakat Kepulauan Aru tentu merupakan referensi paling penting juga dalam melirik potensi sumber daya alam yang akan dikembangkan sebagai investasi masa depan di Kepulauan Aru.

Kepulauan Aru merupakan pulau kecil yang telah memberikan isu besar dalam pengelolaan wilayah perbatasan di Indonesia
Kepentingan negara untuk menjembatani berbagai kepentingan daerah wilayah perbatasan adalah mutlak dilakukan sebagai bukti serius pemerintah dalam memberdayakan masyarakat di wilayah perbatasan. Banyak sumber kekayaan budaya yang belum tergali dari sejumlah pulau-pulau kecil terdepan di Kepulauan Aru hal ini mengingatkan pada sistem pengelolaan sumber daya masyarakat kepulauan yang hidup di daerah perbatasan. Nilai nasionalisme masyarakat kadang terganjal dengan adanya akses pelayanan publik, hal ini sangat mempegaruhi hubungan negara tetangga dengan masyarakat pendukung kebudayaan tersebut. Belajar dari kasus klaim kebudayaan oleh Malaysia terhadap sejumlah karya budaya Indonesia. Hal ini juga memberikan ciri buruk terhadap pengelolaan mekanisme masyarakat perbatasan di Indonesia.

\section{PENUTUP}

Integrasi kebangsaan tidak hanya diukur dari sejauh mana program pemerintah dalam melakukan pembagunan diwialayahwilayah dengan tingkat konsentrasi dan pendapatan besar bagi devisa negara, akan tetapi unsur penyatuan pulau-pulau kecil terdepan sebagai bagian dari negara kesatuan Repbulik Indoensaia menjadi penting dalam sistem pengelolaan secara terpadu dan terencana. Pembahsan isu wilayah perbatasan dan sejumlah kasus yang menimpa kedaulatan bangsa Indonesia tentu memberikan potret buruk bangsa ini dalam mengelola sumber daya yang ada di pulau-pulau tersebut. Makna pulau kecil sering terabaikan dalam pikiran pengambil kebijakan akibatnya pulau kecil terdepan yang disebut terluar seringkali mendapatkan perlakukan tidak seimbangan dengan pulau besar yang ada di Indoensaia. Kepulauan Aru menjadi catatan penting dalam pengelolaaan sumber daya wilayah perbatasan di Indonesia. Kepulauan Aru banyak menyimpan beragam peristiwa sejarah, budaya dengan dilengkapi sumber daya alam yang memukau tentu akan banyak menarik perhatian negara-negara tetangga untuk melakukan berbagai aktivias yang meliputi berbagai tindakan kejahatan, terorisme, ilegal fishing, loging dan sebagainya. Penempatan pusat pertahanan dan keamanan melalu patroli laut yang dilakukan TNI-AL yang berpusat di Kalar-Kalar tidaklah cukup untuk menetralkan berbagai gejolak yang ada. Naumun lebih dari pada itu pentingnya berbagai program pemerintah yang disiapkan guna pembedayaan masayrakat di Kepulauan Aru sebagai masyarakat yang hidup di pulau terdepan yang penting untuk diperhatikan.

\section{$* * * * *$}

\section{DAFTAR PUSTAKA}

Alwi. Des. 2006. Sejarah Banda Naira. Malang. Pustaka Bayan.

Asnan. Gusti. 2007. Dunia Maritim Pantai Sumatera. Jogjakarta: Penerbit Ombak.

de Jong. Nico dan Van Dijk. Tos., 2011. Forgathen Ambon: Balai Pelestarian Sejarah dan Nilai-Nilai Tradisional Ambon.

Lapian. A.B., 2011. Orang Laut Bajak Laut-Raja Laut. Jakarta: Komunitas Bambu.

Sool. A.P.C., 2009. Sejarah Gereja Katolik di Kepulauan Aru. Jogjakarta: Kanisisus.

Susilo. Budi., 2007. Mengembangkan Wawasan Nusantara Masyarakat Indonesia. Makalah dalam Seminar Nasional Direktorat Geografi Sejarah.

Ulean. Alex J., 2012. Sejarah Wilayah Perbatasan Miangas -Filipina. Jakarta: Gramata
Publising.

Wallace, Alfred Russel., 2009. Kepulauan Kajian Manusia dan Alam. Jakarta: Komunitas Bambu.

Wempi, Darmapan., 2012. Letay Sebagai Kearifan Lokal Masyarakat Aru. Makalah disampaikan pada Dialog Budaya Daerah Nilai Budaya Ambon. 
Wakim, Mezak. 2011. Banda Naira Dalam Perspektif Sejarah. Ambon: Balai Pelestarian Nilai Budaya Ambon.

Yani, Yanyan Mohamad. 2008. Pengamanan Wilayah Perbatasan Darat Guna Mendukung Keutuhan Negara Kesatuan Republik Indonesia. Makalah Disampaikan pada acara Roundtable Discussion "Lemhannas RI, Jakarta, 11 Nopember 2008.

Ricklefs, M.C., 2010. Sejarah Indonesia Modern: 1200-2008. Cetakan Ketiga-November 2010. Jakarta: Serambi Ilmu Semesta.

Satria, Arif. 2009. Ekologi Politik Nelayan. Yogyakarta: LKiS

Spriggs, Matthew., O'Connor,S., and Veth, Peter., 2005. The Aru Islands in Perspective: A General Introduction. Dalam The Archaeology of The Aru Islands, Eastern Indonesia. Edited by Sue O'Connor, Matthew Spriggs, and Peter Veth. The Australian National University. 